\title{
APPLYING THE INTEGRATIVE APPROACH IN THE PROCESS OF FORMING FUTURE PRIMARY SCHOOL TEACHERS' FOREIGN LANGUAGE COMMUNICATIVE COMPETENCE
}

\author{
Assistant professor, doctoral student Iryna Pinchuk \\ Ukraine, Hlukhiv, Oleksandr Dovzheko Hlukhiv National Pedagogical University; \\ Primary Education Theory and Methodology Department
}

DOI: https://doi.org/10.31435/rsglobal_ws/31032020/6985

\section{ARTICLE INFO}

Received: 16 January 2020

Accepted: 13 March 2020

Published: 31 March 2020

\section{KEYWORDS}

foreign language communicative competence,

integration,

applying the integrative approach, intending primary school teachers, forming communicative competence.

\begin{abstract}
The article deals with proving the advantages of multi-subject integrated training. It was defined the importance of taking into account the theoretical and methodological foundations of using an integrative approach in the process of forming future primary education teachers' foreign language communicative competence. It was determined the specifics of conducting integrated courses, practical classes, including binary ones, in order to implement the professional training of future primary school teachers according to time requirements. The integration principle corresponds to the mental and physiological nature of the individual, through integration of a person-centered approach to training, as the student is able to choose basic knowledge and skills in different subjects and to apply them in practice.
\end{abstract}

Citation: Iryna Pinchuk. (2020) Applying the Integrative Approach in the Process of Forming Future Primary School Teachers' Foreign Language Communicative Competence. World Science. 3(55), Vol.3. doi: 10.31435/rsglobal_ws/31032020/6985

Copyright: (C) 2020 Iryna Pinchuk. This is an open-access article distributed under the terms of the Creative Commons Attribution License (CC BY). The use, distribution or reproduction in other forums is permitted, provided the original author(s) or licensor are credited and that the original publication in this journal is cited, in accordance with accepted academic practice. No use, distribution or reproduction is permitted which does not comply with these terms.

Introduction. Integration processes are a priority in the overall development of education and are aimed at realizing many of its principles: the forming a holistic picture of the world, planetary thinking, the ability to unite narrow sectoral problems in a single holistic system, the national education orientation principle, which involves integration of national history, the Ukrainian culture, traditions, the openness of education, which in turn leads to integration into the educational spaces world. It is clearly conditioned by the Concept of the New Ukrainian School, the Law of Ukraine on Education, new educational standards and other normative-legal documents [1].

The purpose of the study is to highlight the importance of implementing methodological foundations of using an integrative approach in the professional foreign language training of future primary school teachers; to determine the specifics of conducting integrated courses and practical classes in the process of forming foreign language communicative competence.

Research results. The problem of integration was interested by Ukrainian researchers, in particular, philosophers (V. Andrushchenko, V. Lutai), didactics scientists (S. Honcharenko, O. Danylyuk, I. Kozlovska, L. Masol, O. Savchenko, etc.).

The Ukrainian philosopher V. Lutai notes that using an integrative approach it is possible to rethink the issues of historical developing the culture and the aesthetic consciousness of society [2]. The author is convinced that the modern philosophy of education, which is developed on the basis of a synergistic approach, plays an important methodological role in the new combination of all educational subjects, where the teaching of natural and humanitarian subjects will be organically interconnected, will promote mutual penetration into one [2]. 
The researcher N. Antonova thinks "integration is the process of interpenetration, compaction, unification of knowledge, manifested through unity with the process of dismemberment, demarcation, differentiation opposite to it" [3, p. 4]. I. Kozlovskaya defines this term as "the process of convergence and communication of the sciences, which acts in conjunction with the process of differentiation, which is the highest form of embodiment of inter-subject connections and leads to the formation of integrity" [4, p. 4]. I. Beh is convinced that integration today is an important prerequisite for modern science and the development of civilization as a whole. Integration is seen as a requirement for unification into a whole of any parts or elements, and is expressed as a necessary didactic tool by which a holistic picture of the world can be created in the students' understanding [5, p. 5-7].

Integration in education is a fundamental principle of its organization. Its key advantage is that students can see a holistic picture of the world and get the skills they need in real life.

The term "integration" has a general scientific meaning and is often used in didactics. In the educational process, integration emerged as the opposite of the differentiation of knowledge. It is based on four basic principles:

1) the student relies on knowledge in many subjects;

2) the disciplines are interrelated;

3) homogeneous objects converge;

4) common features for a number of subjects are found and developed [6].

The current task of higher education in the context of an interdisciplinary approach is determined by the tendencies of integration of science, namely:

- combining related material of several subjects around one topic, eliminating duplication in the study of issues;

- consolidation of knowledge, i.e. reconstruction of a fragment of knowledge in order to spend less time for its assimilation, as well as paying attention to the formation of equivalent, general and technological skills;

- mastering significant amount of educational material, the achievement of the integrity of knowledge by students;

- involving students in knowledge acquisition;

- forming the student's creative personality and his / her abilities;

- providing students with the opportunity to apply the acquired knowledge in various academic subjects in their professional activities [7].

Based on the above mentioned, it can be argued that the using an integrative approach in the content of professional training, synchronization of the study of related educational material in different courses, as well as the maximum using different courses' knowledge in order to study complex objects and concepts is an important condition for the effectiveness of the educational process during forming foreign language communicative competence of future primary school teachers. The synchronization of knowledge causes certain changes in the curricula, the need to review the pace of study of courses in order to provide a scientific basis for the formation of future specialists' professional competence.

The Ukrainian scientist L. Biryuk understand integrated training of future primary school teachers as the organization of a pedagogical process on the basis of subject-subjective interaction, which involves the developing their critical and creative thinking and is carried out through the systematization of knowledge in related subjects, facilitating the formation of personality's understanding holistic world picture [7].

In modern education, cross-curricular integration has become common, carried out in different ways [6]:

- creation of integrated courses - academic subjects that adapt to study and integrate knowledge of several sciences;

- developing new forms of lessons / lessons (cross-curricular lesson, integrated hands-on, binary, educational event, etc.);

- development and implementation of educational and scientific projects;

- organization of thematic weeks and days on the particular courses.

Understanding the specifics of integrated training will help to develop and implement integrated training courses curricula in the process of forming foreign language communicative competence during professional training of future primary education professionals. In our opinion, it is possible to integrate different linguistic courses (for example English for professional purposes, Practical course of English, 
English teaching Methodology) in the process of training guidance in order to form a professional communicative competence, which is one of the leading abilities of future primary school teachers.

Integrated practical class is also a powerful stimulator of students' mental activity through the using a block of material from different courses, works of art, problem-type tasks and interactive methods of working with them. In the process of such activities, intending primary school teachers begin to analyze, compare, and seek connections between subjects and phenomena. The implementation of an integrative approach turns a class into an attractive form of study. Another, unusual kind of work stimulates students' interest, their activity.

Researchers of the pedagogical process distinguish internal integration (for example, the combination of language learning and the teaching methods) and external integration (for example, the combination of educational programs in history, fine arts, and music with the teaching of language). Therefore, an integrative approach to the professional training of future primary school teachers requires overcoming narrow-minded stereotypes, an orientation on integrated learning, in particular, the creation of integrated courses, and the integration processes of such training should be aimed at forming a holistic world understanding by future professionals.

Scholars identify binary lectures / classes as a kind of integration of the two courses. For example, we consider the following productive kinds of integration: lectures on contemporary English language and contemporary English literature; modern English literature and history; contemporary English literature and fine arts; modern English literature and music, etc. Binary practical classes expand the vocabulary, promote forming foreign language professional communicative competence, and are a powerful stimulator of critical, intuitive, creative thinking. The using an integrative approach in the process of intending teachers' professional training helps to create a different emotional atmosphere, open up creative abilities, promote the development of their thinking and imagination during forming foreign language communicative competence.

Integration can involve using the content not only two, but also the material of three or four courses: Didactics, English teaching methods; Education history, Pedagogy, Psychology, Linguistics; Theory of text types, Literary reading, etc. Developing an integrated practical class structure is a common subject matter for faculty members. Such classes may be conducted by one teacher or several pedagogues of different courses.

During the preparing for future professional activity, intending primary school teachers will get acquainted with the specifics of the organization of integrated learning in practice according to the requirements of the Concept of the New Ukrainian School. In today's primary school, in particular in the first and second forms, integrated weeks are practiced, planned and prepared by the teachers in advance. In the course of the thematic weeks, integration of three or even four primary school subjects is possible. So, intending primary school teachers should be ready to create such kind of integrated week [8].

The most common type of integrated classes used in our higher educational institution is "The English language - English teaching methodology", "English literature - English-speaking country study". Any literary work, word or phrase reflects the features of a particular historical path. An analysis of a creative literature work is necessarily based on the understanding of vocabulary and the peculiarities of the time of the story.

Intending primary school teachers should know the structural components of integrated class as the most common form of integrated learning.

According to the content, integrated classes are divided into four types:

- introductory - for studying a certain topic (section, chapter);

- studying new material;

- final (generalization and systematization);

- control.

In the introductory sessions, they describe in a descriptive way a general picture of the phenomena they will study. This can be a paired class with several teachers working. Common knowledge is put into practice.

On the introductory integrated classes, a teacher presents a general picture of the studying phenomena in a descriptive way. It can be a paired class (for two or more courses) with several teachers working. Common knowledge is put into practice.

After studying a particular section or topic, where students have a thorough knowledge of the presented material, final integrated classes are held. Teachers use already known for students material, explain a new amount of facts, various processes, and open the knowledge prospects on this topic. 
It is advisable to carry out a test section in the course of controlling knowledge in the final study of a particular section in which it is necessary to determine the appropriate students' levels of mastering learning material. It is important to select the tasks for control taking into account the integration of the studied material.

Many scientists and teachers have a great interest in the problem of interaction between subjects of humanitarian and aesthetic cycles. This interest is motivated by the fact that a comprehensive study of the material leads to a deeper understanding of the laws, contributes to the formation of their own conclusions, a broad scientific outlook [9].

An important component of the success of an integrated lesson is the appropriate selection of tasks and courses. Typical examples of integrated tasks and activities are listed below:

- reading a literary work and comparing it with a historical document;

- observing the expressive function of linguistic means, reciting poetry, comparing poetic lines with the artistic picture;

- expressive reading of a prose work, selection of language means, painting drawings for episodes of a work, making a dialogue;

- using the texts about heroic pages of English history for listening and retelling;

- supplementing or disseminating the story about the characters with the information from the story, drawing parallels with Ukrainian literary works, listening to musical works according the topic, applying game moments.

In the study of folk legends and songs, works on historical topics we should use a rich illustrative base: samples of folklore, musical works of famous composers, samples of folk art, reproductions of paintings, illustrations, author's works, vocal performances of the students themselves. The teacher should carefully select literary fragments, select such extracts of works that would evoke the students' respective emotions and stimulate reflection. The same requirements apply to an illustrative base designed to more clearly convey the atmosphere of times past, the drama, outlook and traits of human consciousness of ancient epochs, but by no means idealize historical figures [8].

Despite the positive use of the integrated approach in the educational process, the researchers highlight some of the difficulties and disadvantages that may occur in the preparation and implementation of various forms of integrated learning, in particular: increasing the density of teacher's employment; due to the large amount of material, it is likely not to be considered in detail; preparation of the lesson requires considerable time; cooperation of different specialists is not always possible for different reasons and circumstances; inability to carry out such lessons often due to the workload of teachers; both subjects cannot be equally represented in the same lesson; the opinion of one of the participants in the educational process (the teacher) may not coincide with the opinion of the other, the positions of the parties are clarified in advance [10].

The advantages of multi-subject integrated training over traditional single-subject are obvious: it is possible to create more favorable conditions for the development of intellectual skills of students, to learn to apply theoretical knowledge in life practice, specific professional situations, in new atypical conditions. Mastering integrative activity in the complex optimizes intelligence, critical and creative thinking, imagination, that is, forms those abilities that will be required in any field of activity, including foreign language communicative competence. Integrated lessons bring the process of professional training to life, naturalize it, and make sense of it. The use of an integrative approach in pedagogical higher education institutions meets the requirements of today and the requirements of the New Ukrainian School Concept, in particular, which will be implemented by modern students intending primary school teachers.

Conclusions. Implementing integrative approach in the educational process in higher educational pedagogical institutions allows forming a holistic picture of the intellectual development of mankind in the systemic connections of different branches of knowledge. The multicomponent content of education enables the teacher to rationally allocate time for studying the courses, to reduce the number of hours for their study, and at the expense of the free time to organize work aimed at developing creative abilities, forming foreign language communicative competence and pedagogical experience of intending primary school teachers. The ability to work in the context of an integrative approach ensures the formation of a holistic system of professional qualities, in particular, the development of integrative and communicative abilities of future primary school teachers. 


\section{REFERENCES}

1. Національна стратегія розвитку освіти в Україні на період до 2021 року [Електронний ресурс] Режим доступу: http//zakon2.rada.gov.ua/laws/show/344/2013.

2. Лутай В.С. Філософія сучасної освіти: навч. посібник. К.:Центр «Магістр» Творчої спілки вчителів України, 1996. $256 \mathrm{c.}$

3. Антонова Н.С. Інтеграційна функція навчання. К: Освіта, 1989. 304 с.

4. Козловська І.М. Теоретико-методологічні аспекти інтеграції знань учнів професійно-технічної школи: дидактичні основи: монографія / за ред. С.У. Гончаренка. Львів : Світ, 1999. 302 с.

5. Бех І. Д. Інтеграція як освітня перспектива. Початкова школа. 2002. №5. С.5-7.

6. Голубенко С.М. Формування комунікативної компетентності майбутніх учителів початкових класів у процесі впровадження інтегрованих форм навчання. Особистісно-професійна компетентність педагога: теорія і практика: матеріали III Всеукраїнської науково-методичної конференції (20 лютого 2019 р.). /за заг. ред. Л.В. Серих. Суми : НІКО, 2019. С. 63 - 64.

7. Бірюк Л. Я., Пішун С. Г. Інтегративний підхід до професійної підготовки майбутніх учителів початкової освіти. Вісник Глухівського наиіонального педагогічного університету імені Олександра Довженка : педагогічні науки. Випуск 1 (42). Глухів. 2020. С. $19-28$.

8. Нова українська школа: порадник для вчителя / під заг. ред. Н.М. Бібік. К.: ТОВ «Видавничий дім Плеяди», 2017. 206 с. URL: http://nus.org.ua.wp-content/uploads/2017/11/NUSH-poradnyk-dlyavchytelya.pdf] (дата звернення 11.02.2019).

9. Підготовка вчителя іноземної мови (англійської) для Нової української школи: колективна монографія / Мілютіна О. К., Лавриченко Н. М., Заремська І. М. та ін.; за заг. ред. Н. М. Лавриченко. Суми: видавничо-виробниче підприємство «Мрія», 2018. 280 с.

10. Ляшенко О.І. Стратегія якості як основа освітньої політики країн світу. Моніторинг якості освіти: світові досягнення та українські перспективи : посібник / за заг. ред. Локшиної О.І. МОНУ. К. : K.I.C., 2004. C. 9 - 14. 